\title{
FÉMFORGÁCSOLÁSI FOLYAMATOK SZIMULÁCIÓJA
}

\section{SIMULATION OF METAL CUTTING PROCESSES}

\author{
Dezső Gergely ${ }^{1}$, Szigeti Ferenc ${ }^{1}$ \\ ${ }^{I}$ Nyirregyházi Főiskola (Müszaki és Agrártudományi Intézet, Müszaki Alapozó, Fizi- \\ ka és Gépgyártástechnológiai Intézeti Tanszék) H-4400 Nyirregyháza, Sóstói út 31/b \\ Telefon+36-42-599400 / Fax: +36-42-402485, dezsog@nyf.hu
}

\begin{abstract}
Nowadays environmentally friendly production is an important branch of environmentally conscious design. Environmentally frienrly cutting can decrease energy consumption and costs of handling polluting materials. In this paper first main features of metal cutting treated, then a simple model and its solution is presented.
\end{abstract}

Keywords: cutting, simulation, environmentally conscious

\section{Összefoglalás}

A környezettudatos terméktervezés egyik fontos ága a gyártástervezés. A környezetbarát fémforgácsolás csökkentheti az energiafelhasználást és a káros anyagok kezelésével kapcsolatos költségeket. Ez a dolgozat a fémforgácsolás sajátosságainak áttekintését követően a forgácsolásnak egy modelljét és annak megoldását mutatja be.

Kulcsszavak: forgácsolás, szimuláció, környezettudatos

\section{Bevezetés}

Napjaink egyik intenzíven kutatott, ugyanakkor jelenleg is számos megoldásra váró kérdést magában rejtő témája a környezettudatos terméktervezés. A Nyíregyházi Főiskola Müszaki Alapozó, Fizika és Gépgyártástechnológiai Tanszéke elsősorban környezetbarát fémforgácsolási technológiákkal foglalkozik, amelyek segíthetik az energiafelhasználás csökkentését és a káros anyag kibocsájtást. Minimál kenéssel végzett fúrásra vonatkozó kísérletek alapján összefüggést állítottunk fel a felületminőség és a hütő-kenőanyag adagolásának üteme között. Kimutattuk, hogy a szerszámkopás hogyan függ a hütő-kenőanyag mennyiségétől.
A szimulációk célja az elméleti modellek felállítása és alkalmazása a fémforgácsolás jelenségeire. Ebben az összefoglalóban a fémforgácsolási folyamatok szimulációjának fö sajátosságaira szeretnénk rámutatni, valamint bemutatunk egy egyszerü modellszámítást.

\section{A fémforgácsolás során fellépő sajátos jelenségek}

A forgácsleválasztási folyamatban nagy erők és nagy feszültségek lépnek fel $[2,3]$. Az anyagszétválás során az anyag teherviselő képességének megszűnése miatt az erőrendszer gyors átrendeződésére és lökésszerü változásokra kell számítani igen rövid idő alatt. 
A fémforgácsolás során a szerszám nagy sebességgel hatol be a munkadarabba, emiatt az anyagszétválasztás során bekövetkező alakváltozás különös figyelmet érdemel. A maradandó alakváltozás döntő része egy, a szerszám élének környezetében elhelyezkedő, de a folyamat során a helyét változtató, kicsiny térrészben következik be. Az alakváltozás igen jelentős a szerszám környezetében, és nagy az alakváltozás hely szerinti megváltozása (gradiense) is. Az alakváltozási sebesség rendkívül nagy lehet, elérheti akár a $10^{3}-10^{6} \frac{1}{\mathrm{~s}}$ értéket is a forgácsolási paraméterektől függően.

A deformációs zónában a hőmérséklet akár $1200{ }^{\circ} \mathrm{C}$ fölé is emelkedhet. A hőmérséklet gradiense igen nagy $1000{ }^{\circ} \mathrm{C} / \mathrm{mm}$ lehet bizonyos tartományokban. A hömérséklet idő szerinti változása is nagyon gyors a forgácsleválasztás pályája mentén.

A munkadarab anyaga a deformációs zónában szélsőséges körülmények közé kerül, ezért különös jelentősége van annak, hogy az anyagjellemzőknek más mennyiségektől (például a hőmérséklettől, alakváltozástól, alakváltozási sebességtől, feszültségállapottól) való függését le lehessen írni.

Megemlítendő, hogy fázisátalakulás és kémiai változás is bekövetkezhet a forgácsleválasztás során.

\section{Az érintkezés}

A szimulációban két test érintkezésének leírása kritikus feladat [1]. Ezzel a tribológia foglalkozik, itt csak a legfontosabb vonatkozásokra térünk ki. Az érintkező felületek mentén az alábbi jelenségeket vesszük figyelembe:

- a másik test mozgásának korlátozása (kényszerfeltétel);

- erőátadás;

- az érintkezés környezetében feszültség kialakulása az anyagban;

- súrlódás;

- hőátadás;

- kopás.
Az első három jelenség szorosan összefügg egymással, ezek modellezésekor az egyik legfontosabb kérdés az, hogy mekkora távolságban tekintünk egymással érintkezőnek két pontot (kontakttolerancia), és ezt a távolságot hogy osztjuk el a két test között.

Modellünkben a kopást egyelöre nem építettük be.

A súrlódáskor a felület mentén fellépő feszültség függ a felületeket összenyomó erőtől és a felületek viszonylagos sebességétől, de más mennyiségektől is. A modellezésekor két kritikus kérdés merül fel:

- az irányváltáskor bekövetkező ugrásszerü előjelváltás leírása úgy, hogy a numerikus módszer stabilitása ne kerüljön veszélybe; - a súrlódási erő nagyságának megadása.

A súrlódási erő ugrásszerü megváltozását úgy írjuk le, hogy a lépcsős függvényt arkusz tangens függvénnyel közelítjük. A súrlódási erő nagyságát a normál és az ekvivalens feszültség függvényeként a Wanheim-Bay-közelítéssel írjuk le.

\section{A fémforgácsolás egy modellje}

A fémforgácsolás legegyszerübb esete a gyalulás. Célunk a forgácsoló ék és a munkadarab kölcsönhatásának elemzése.

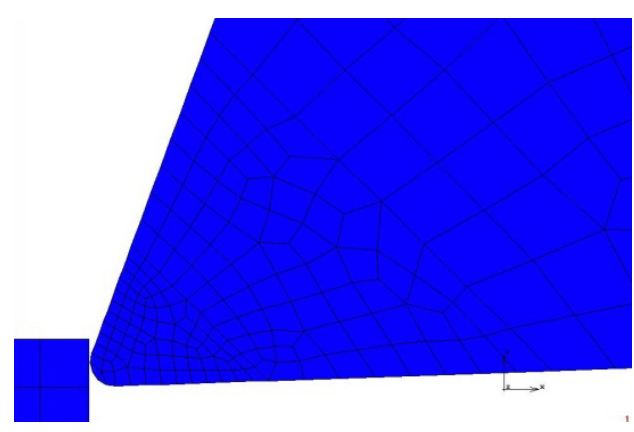

1. ábra. A térbeli diszkretizáció 


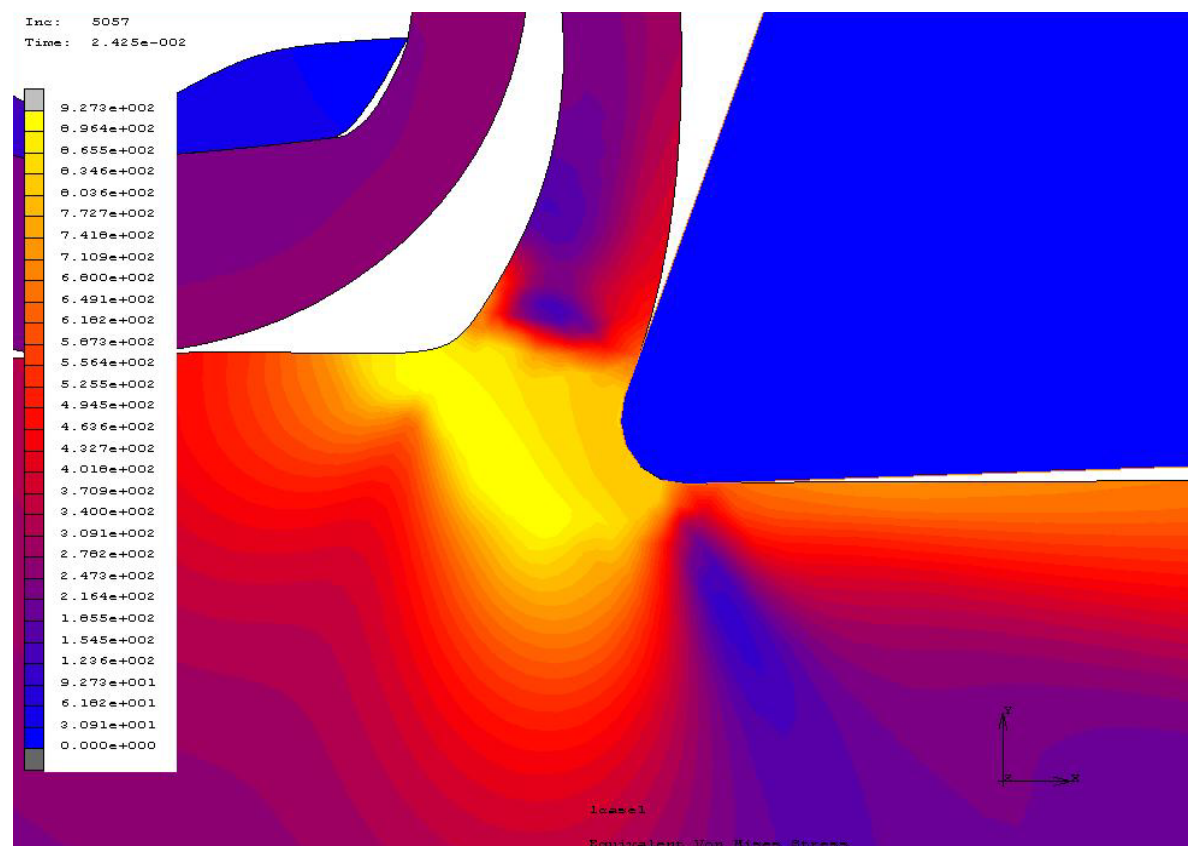

2. ábra. A Mieses szerinti feszültség eloszlása a munkadarabban

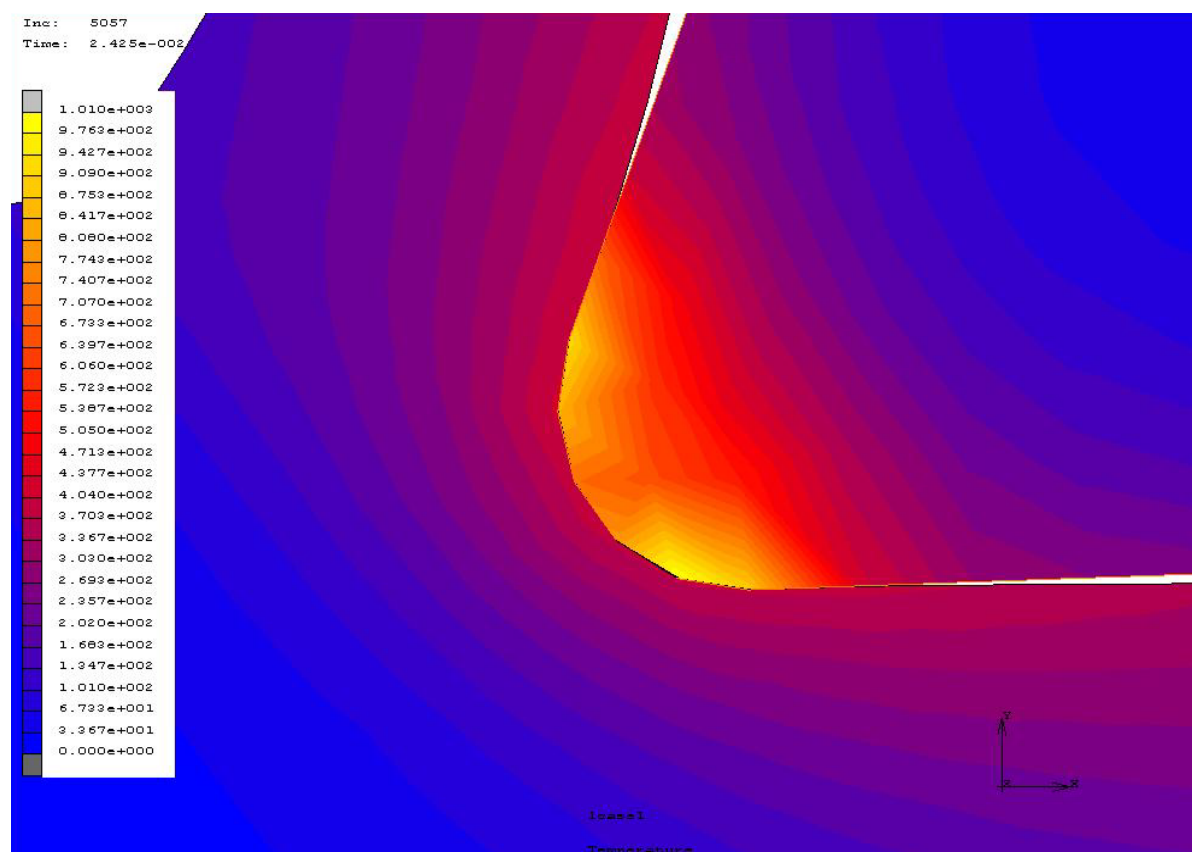

3. ábra. A hömérséklet eloszlása a munkadarabban 


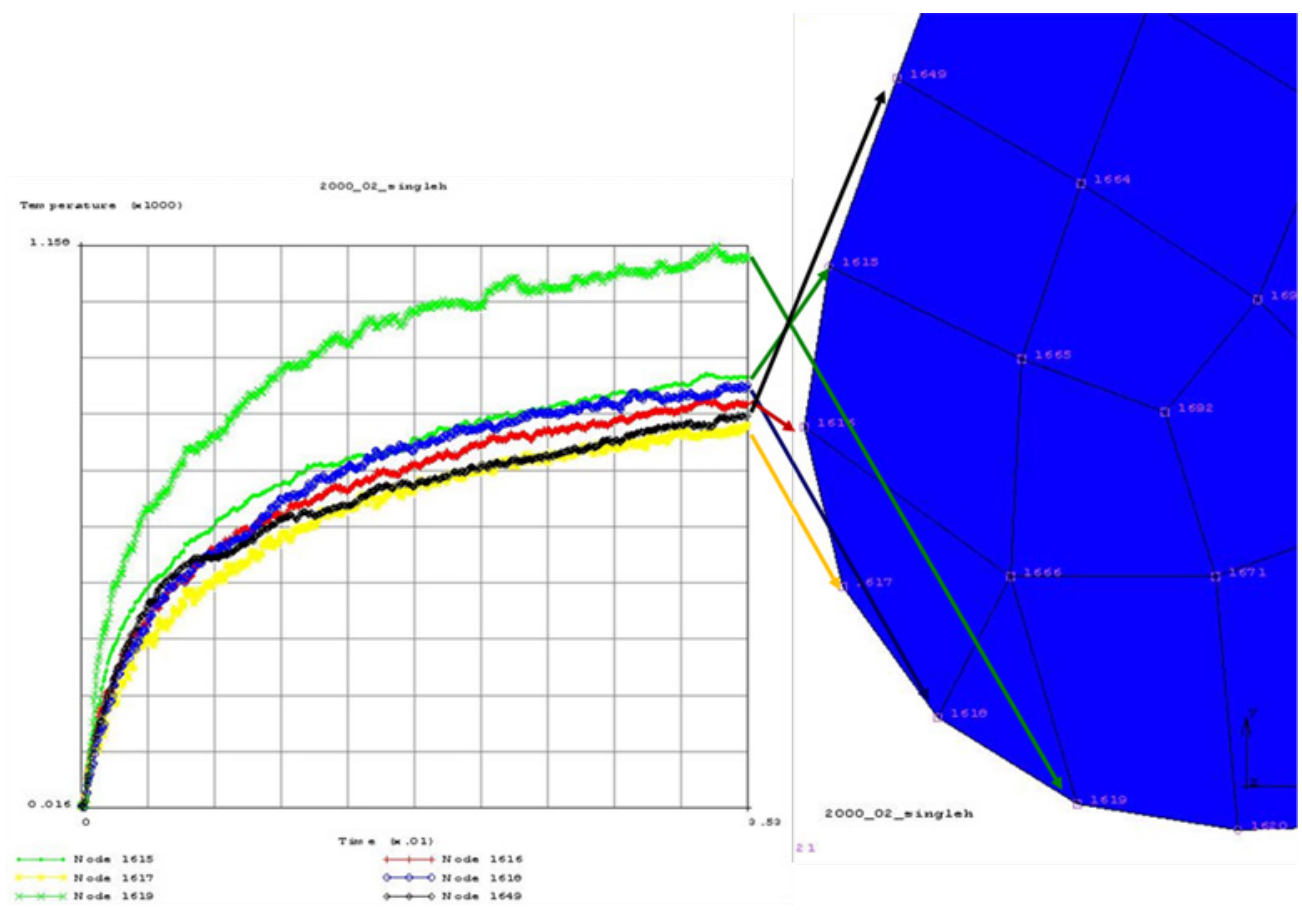

4. ábra. A hömérséklet időbeli változása a szerszám élének bizonyos pontjain

A modellt térben (1. ábra) és időben is diszkretizáltuk. Az így kapott véges elem modell megoldását egy időpillanatban a 2. és 3. ábra szemlélteti.

A szerszámot merev testként modelleztük, ezért abban feszültségállapotot nem számítottunk, a hőtani jelenségeket azonban igen.

A szimulációban a forgácsolási sebesség $120 \mathrm{~m} / \mathrm{min}$, a fogásmélység $1 \mathrm{~mm}$. A munkadarab C35 acél, a szerszám keményfém.

A 3. és 4. ábrák jól mutatják a forgácsoló él melegedésének maximumait. Ez összhangban van a kísérletek során tapasztalt kopással, amit nem modelleztünk ugyan, de ismert, hogy azt a melegedés és a nagy feszültségek segítik elö.

\section{Következtetések}

A dolgozatunkban leírt modellszámítás eredményei azt mutatják, hogy a forgácsleválasztás során fellépő jelenségek figyelembe vételével jó közelítéssel leírható a forgácsolás folyamata.

\section{Szakirodalmi hivatkozások}

[1] Zienkiewicz, O. C.; Taylor, R. L.; Zhu, J. Z.: The finite element method, its basis and fundamentals. Elsevier Butterwort-Heineman Linacre House, Oxford, 2005, ISBN 0-75066320.

[2] Dudás Illés: Gépgyártástechnológia I. Müszaki Könyvkiadó, Budapest, 2011.

[3] Gyáni Károly: Gépgyártástechnológia alapjai I. Tankönyvkiadó, Budapest, 1978. 